\title{
Turkish Adaptation of Nature of Technology Scale
}

\author{
Huseyin ATES ${ }^{1}$, Serbay DURMAZ2 \\ ${ }^{1}$ Ahi Evran University, Department of Science Education, Turkey \\ ${ }^{2}$ AhiEvran University, Graduate School of Natural and Applied Sciences, Turkey \\ 1huseyinates_38@hotmail.com, 2serbaydurmaz@hotmail.com
}

\begin{abstract}
Technology has always existed not for recently. For ages, its effect has occurred on society, economy and politics and evolution of technology is closely related to human development. Accordingly, human needs and desires are satisfied with technological knowledge and problem solving which is seemed as innovative change (International Technology Education Association [ITEA], 2005). However, nature and scope of technology which is a very important place in our lives is not fully understood (Aydin \& Karacam, 2015; Bybee, 2010; DiGironimo, 2011; ITEA, 2006). Researches about nature of technology showed that technology in people's minds remains just as electric products, such as phones or computers (DeVries, 2003; Lewis, 1999; Volk \& Dugger, 2005). Technology should be considered as a whole not one thing that separates the parts (Williams, 2000; Ylldız \& Baltacl, 2016). Understanding nature of technology is possible with only education completely. Since there are limited studies about nature of technology in science education (e.g., Liou, 2015) and is no required number of scales especially in Turkish language, this study is needed. For all of these needs to be resolved, the purpose of this study is to adapt 'Nature of Technology Scale' into Turkish. The sample consisted of 255 pre-service science teachers who enrolled in the faculty of education of a university in Turkey. In the study, as an instrument, "The Student Concepts of the Nature of Technology Questionnaire' developed by Liou (2015) was used. The data in this study were collected in the 2015-2016 spring semester. Data were analyzed with Structural Equation Modeling (SEM) method. According to findings, our data results showed that this study is suitable for Turkish adaptation of scale (CMın/Df, 1.52, GFI, .94, NFI, .92, RMSEA, .04, CFI, .95). Turkish form of the scale has 29 items that fall under 6 factors.
\end{abstract}

Keywords: Nature of Technology, Preservice Science teachers, Turkish Adaptation

\section{Introduction}

In the $21^{\text {st }}$ century, people all over the world have attached the importance to technology in all areas of life and it has become important necessity (e.g., Baltaci \& Yildiz, 2015; Özçakır, Aytekin, Altunkaya, \& Doruk, 2015). Technology has always existed not only for recently. For ages, its effect has occurred on society, economy and politics and evolution of it is closely related to human development. Accordingly, human needs and desires are satisfied with technological knowledge and problem solving seemed as innovative change (Baltacl, Yıldız, Kıymaz \& Aytekin, 2016; International Technology Education Association [ITEA], 2005). However, nature and scope of technology which is a very important place in our lives is not fully understood (Aydın \& Karacam, 2015; Bybee, 2010; DiGironimo, 2011; ITEA, 2006). Researches about nature of technology showed that technology in people's minds remains just as electric products, such as phones or computers (DeVries, 2003; Lewis, 1999; Volk \&Dugger, 2005). Technology should be considered as a whole not one thing that separates the parts (Williams, 2000). Understanding nature of technology is possible with only education completely. Additionally, understanding concept of nature of technology with formal education become effective to provide students' adaptation to modern society and productive citizenship in an information-driven economy because becoming technologically literate is easier for students than adult (DiGironimo, 2011; Liou, 2015).

In addition to being of great importance of education to provide understanding concept of the nature of technology, the level of education is also important. Because students all level have difficulty to understand nature of technology. Among them, students who study in the faculty of education become teacher after graduation and were called pre-service teachers who are going to educate next generations who study at elementary, primary and high school. In the first stage, pre-service teachers should be educated rather younger students. The reason why importance is given to pre-service teachers is that they learn and transfer what they have learned. Misconceptions teachers taught are not easily corrected. There are many studies about topics in nature of a concept. For example, studies in nature of science (e.g., 
Akindehin, 1988; Kang, Scharman, \& Noh, 2004; Lederman, 1986; Zeidler, Walker, Ackett, \& Simmons, 2002 etc.) showed that problems were occurred in terms of students and teachers' conceptions and teaching and learning nature of science, though limited studies are conducted in nature of technology (DiGironimo, 2011; Liou, 2015; Raat \& de Vries, 1987). Studies indicated that pre-service science teachers also have difficulty to understand concept of the nature of technology (e.g., Liou, 2015). In Turkey, understanding importance of technology is one of the purposes of science education courses according to science education curriculum published in 2013 and this topic is involved among four learning areas. Since there are limited studies about nature of technology in science education (e.g., Liou, 2015) and no required number of questionnaire especially in Turkish language (e.g., Aydın, 2009; Zorlu, 2011), scale in Turkish language is needed in order that researchers use. For all of these needs to be resolved, the purpose of this study is to adapt 'Nature of Technology Scale' into Turkish.

\section{Method}

The sample consisted of 255 pre-service science teachers who enrolled in the faculty of education of a university in Turkey. This university was selected since they are convenient for the researchers. Namely, convenience sampling which is the most appropriate sample for researchers was used (Fraenkel, Wallen \& Hyun, 2012). The study was conducted on 51 males (20\%) and 204 females (80 \%) whose mean age was 20.53 (range: 18 27). The four groups comprised 86 freshmen 98 sophomores, 37 juniors and 34 seniors.

Instrument: In the study, as an instrument, 'The Student Concepts of the Nature of Technology Questionnaire' developed by Liou (2015) was used. Original language of scale is English. However, researchers in our study conducted this study for adaptation of this scale to Turkish. Before adaptation of this scale to Turkish, necessary permissions were got from authors who developed English version of this scale. Scale consists of 29 items from strongly agree (5) to strongly disagree (1) with five-point Likerttype.

Data Collection: The data in this study were collected in the 2015-2016 spring semester. Ethical permission from the ethical committees at the university was obtained prior to conducting the study. A signed consent form was returned by the participating pre-service science teachers in order to confirm that they voluntarily agreed to participate in this study. To ensure consistency in data collection, only one author administered the scale. The scale took approximately 20 minutes to complete.

Data Analysis and Translation Process: Before the translation process started, some criterions about translators stated by Savaşır (1994) were determined: Translators should know source and target language at good level, should know issues related to scale and should have experience of both cultures. The scale which is English was carried out a series of operations to be adapted to Turkish determined by Dursun and Aydın (2011) and Hambleton and Bollwark (1991).

- Items in the scale were translated to Turkish and items in Turkish were translated to English with back-translation methods to elaborate semantic shift because of translation.

- Translation and back-translation were carried out by three translator and Turkish items were obtained as a result of the evaluation of two language education experts.

- Linguistic equivalence study was conducted to ensure consistency between the original form and translation to Turkish version.

- To ensure the consistency of scores the between the two languages, firstly English version of scale and then Turkish version of scale were conducted with 50 pre-service English teachers.

- Pearson product-moment correlation coefficient was calculated. This coefficient showed that positive and significant relationship were found between English and Turkish scales $[r(50)=0.93$, $\mathrm{p}<.05]$.

For data analysis, confirmatory and explanatory factor analyses were performed. In addition, data were analyzed with Structural Equation Modeling (SEM) method. We identified relationship between variables 
in the model with SEM method. The factors included in the model were determined by the SPSS Amos program to prepare Structural Equation Modeling.

\section{Findings}

Exploratory and confirmatory factor analyzes were used together for adaptation of scale into Turkish. The analysis of the data took place in three stages. In the first step, before factor analysis, reliability analysis was performed and this analysis showed that the reliability coefficient, cronbach alpha ( $\alpha$ ), was determined as 0.93 . In the second step, factors belonged to the nature of the technology involved in the original test were determined with exploratory factor analysis. In order to understand if scale is appropriate for factor analysis, Barlett and Kaiser-Meyer-Oklin (KMO) test results were analyzed. Since KMO (.85) is .6 or upper and Barlett value (.000) is 0.5 or below, it can be stated that test is suitable for factor analysis (Pallant, 2005). Similar to the results of the Liou (2015), after the exploratory factor analysis, scale includes six dimensions including (1) "Technology as artifacts", (11) "Technology as an innovative change", (III) "The current role of technology in society", (Iv) "Technology as a double-edged sword", (v) "History of technology" and (vi) "Technology as a science-based form" (Liou, 2015). The first dimension contains four items, while others do five items. These factors in the original test were then determined by confirmatory factor analysis. Structural equation modeling which is an analysis that evaluates the suitability of the model has been used to perform confirmatory factor analysis. Obtained factors are indicated in Table 1.

\section{Table 1: Principal axis factor analysis of the scale with varimax rotation}

\begin{tabular}{|c|c|c|c|c|c|c|}
\hline \multicolumn{7}{|c|}{ Factors } \\
\hline Items & $1(\alpha=.84)$ & $2(\alpha=.87)$ & $3(\alpha=.86)$ & $4(\alpha=.89)$ & $5(\alpha=.86)$ & $6(\alpha=.88)$ \\
\hline 1 & .81 & & & & & \\
\hline 2 & .80 & & & & & \\
\hline 3 & .69 & & & & & \\
\hline 4 & .75 & & & & & \\
\hline 5 & & .58 & & & & \\
\hline 6 & & .56 & & & & \\
\hline 7 & & .68 & & & & \\
\hline 8 & & .66 & & & & \\
\hline 9 & & .56 & & & & \\
\hline 10 & & & .52 & & & \\
\hline 11 & & & .48 & & & \\
\hline 12 & & & .59 & & & \\
\hline 13 & & & .58 & & & \\
\hline 14 & & & .66 & & & \\
\hline 15 & & & & .67 & & \\
\hline
\end{tabular}




\begin{tabular}{|c|c|c|c|}
\hline 16 & .75 & & \\
\hline 17 & .80 & & \\
\hline 18 & .72 & & \\
\hline 19 & .69 & & \\
\hline 20 & & .53 & \\
\hline 21 & & .56 & \\
\hline 22 & & .65 & \\
\hline 23 & & .65 & \\
\hline 24 & & .58 & \\
\hline 25 & & & .73 \\
\hline 26 & & & .72 \\
\hline 27 & & & .70 \\
\hline 28 & & & .80 \\
\hline 29 & & & .68 \\
\hline
\end{tabular}

Note: The overall Cronbach's alpha value $=.93$.

Model fit indices are named $\chi 2, \chi 2$ / sd, GFI, AGFI, RMSEA, RMR, SRMR. Compliance indices are very diverse, but it is reported that there is not a full consensus on which of these compliance indices will be accepted as the standard (Munro, 2005).

For model conformity, following calculations have been made: CMIN/DF $\left(\mathrm{chi}^{2} /\right.$ degrees of freedom $)=$ 1,52, GFI (goodness-of-fit index) $=0.94$, CFI (comparative fit index) $=0.95$, NFI (normed fit index) $=0.92$ and RMSEA (root mean square error of approximation) $=0,04$. CMIN/DF should become lower than 3 (Kline, 2005; Mcdonald \& Ho, 2002). The GFI value takes between 0 and 1 and this value determine suitability of the model. The more value close to 1 , the more model is convenient and the more value become distant from 1, the less model is appropriate. GFI, CFI, and NFI values should be above 0.90 and RMSEA value should be below 0.08 (Hu \& Bentler, 1999; Schreiber, Stage, King, Nora, \& Barlow, 2006). Findings toward Model fit indices are indicated in Table 2.

Table 2: Model fit indices

\begin{tabular}{llll}
\hline Compliance Measure & Good Compliance & Acceptable Compliance & Values of Model \\
\hline$\chi^{2} / \mathrm{df}(\mathrm{CMIN} / \mathrm{df})$ & $\leq 3$ & $\leq 4-5$ & 1,52 \\
GFI & $\geq 0,90$ & $0,85-0,89$ &, 94 \\
CFI & $\geq 0,97$ & $\geq 0,95$ &, 95 \\
RMSEA & $\leq 0,05$ & $0,06-0,08$ &, 04 \\
NFI & $\geq 0,95$ & $0,90-0,94$ &, 92 \\
\hline
\end{tabular}


At the end of the confirmatory factor analysis, the factor structure belonging to the Nature of Technology Scale provides the values of CMIN / DF, NFI, GFI, CFI and RMSEA. The structural equation modeling of the Nature of Technology Scale is an indication of compliance with the predetermined model.

\section{Discussion}

Among the aims of the science education curriculum, the students are aware of the fact that science affects the technology and the technology affects the knowledge. The updated science education program consists of four learning areas. These are knowledge, skills, emotion, and science-technology-societyenvironment (FTTÇ). The nature of technology is directly related to both emotion such as value (ITTC, 2006) and science-technology-society-environment learning. All findings performed for the Turkishadapted test showed that the test can also be used in the Turkish sample.

Taking into consideration the technological equipment of the school, the teachers and the students, the integration of the technology into the inquiry process can be achieved. Another highlight of understanding the nature of technology is the projects that are conducted for technology-supported education such as the Fatih project (Movement to Increase Opportunities and Technology) in Turkey. For all these reasons, it is important to use a scale adapted into Turkish toward the nature of technology. Even though there are some efforts toward adaptation of nature of technology scale into Turkish (e.g., Aydın, 2009; Zorlu, 2011), this study focused on the topic from a different point of view.

Recommendations: Teachers can use this scale to determine students' attitude and beliefs toward nature of technology in terms of various variables. In addition, researchers can use multiple methods and measures to by expanding this nature of technology scale. Using this scale, significant changes in students' beliefs about the nature of technology can be observed with longitudinal researches. A qualitative scale can be conducted by considering the dimensions of the scale and the materials.

\section{References}

Akindehin, F. (1988).Effect of an instructional package on preservice Science teachers' under- standing of the nature of Science and acquisition of science-related attitudes. Science Education, 72(1), 73-82.

Aydın, F. (2009).Development of pre-service science teachers' views and concepts about nature of technology and effectiveness of dilemmas in teaching, Unpublished $\mathrm{PhD}$ thesis, Ankara, Turkey

Aydın, F., \& Karacam, S. (2015). Using of newspapers' news on development of pre-service teachers' views on the nature of technology, Journal of Educational Sciences, 41, 1-17.

Baltaci, S., \& Yildiz, A. (2015).Geo Gebra 3D from the perspectives of elementary pre-service mathematics teachers who are familiar with a number of software programs. Cypriot Journal of Educational Sciences, 10(1),12-17.

Baltacı, S., Yıldız, A., Kıymaz, Y., \& Aytekin, C. (2016). Üstünyetenekliöğrencilereyönelik GeoGebradesteklietkinlikhazırlamakiçinyürütülentasarımtabanlıaraştırmasürecindenyansımalar. Mehmet Akif Ersoy Üniversitesi Eğitim Fakültesi Dergisi, 39, 70-90.

Bybee, R. W. (2010). "Advancing STEM Education: A 2020 Vision." Technology and Engineering Teacher, 70 (1), 30-35.

deVries, M. J. (2003). Editorial. International Journal of Technology and Design Education, 13(3), 199-205.

DiGironimo, N. (2011). "What is Technology? Investigating Student Conceptions about the Nature of Technology." International Journal of Science Education 33 (10), 1337-1352.

Dursun, Ö.Ö. \&Aydın, C. H. (2011). Translation, adaptation and validation of the communicator style instrument into Turkish, Eskişehir Osmangazi Üniversitesi İIBF Dergisi, 6(2), 263-286.

Fraenkel J. R., Wallen N. E., \& Hyun, H. H. (2012). How to design and evaluate research in education, New York, NY: McGraw-Hill.

Hambleton, R. K. \& Bollwark, J. (1991).Adapting tests for use in different cultures: Technical issues and methods. Bulletin of the International Testing Commission, 18, 3-32.

Hu, L.,\& Bentler, P. M. (1999). Cutoffcriteriaforfit indexes in covariancestructureanalysis: conventionalcriteriaversusnewalternatives. StructuralEquationModeling, 6(1), 1-55. 
International Technology Education Association [ITEA]. (2005). Impacts of Technology: A StandardsBased High School Model Course Guide. Reston, VA: Author.

International Technology Education Association [ITEA]. (2006). Technological Literacy for All: A Rationale and Structure for the Study of Technology. Reston, VA: Author.

Kang, S., Scharmann, L., \& Noh, T. (2004).Examining students' views on the nature of science- Results from Korean 6th, 8th, and 10th graders. Science Education, 89(2), 314-334.

Kline, R. B. (2005). Principlesandpractice of structuralequationmodeling(2nd ed.). New York, NY: GuilfordPress.

Lederman, N. G. (1986). Relating teaching behavior and classroom climate to changes in students' conceptions of the nature of science. Science Education, 70(1), 3-19.

Lewis, T. (1999).Research in Technology Education - Some Areas of Need. Journal of Technology Education, 10(2), 41-56.

Liou, P. Y. (2015). Developing an instrument for assessing students' concepts of the nature of technology, Research in Science \& Technological Education, 33(2), 162-181, DOI: $10.1080 / 02635143.2014 .996542$

McDonald, R. P.,\&Ho, M. H. (2002). Principlesandpractice in reportingstructuralequationanalysis. PsychologicalMethods, 7(1), 64-82.

Munro, B. H. (2005). Statistical methods for health care research (Vol. 1). Lippincott Williams \& Wilkins.

Özçakır, B., Aytekin, C., Altunkaya, B., \& Doruk, B. K. (2015). Effects of using dynamic geometry activities on eighth grade students' achievement levels and estimation performances in triangles, Participatory Educational Research, 2(3), 43-54.

Pallant, J., (2005). SPSS survival manual: A step by step guide to data analysis using SPSS for windows (Version 12). (2nd ed.). Maidenhead: Open University Press.

Raat, J. H., \& M. de Vries. 1987. "Technology in Education: Research and Development in the Project "Physics and Technology." International Journal of Science Education, 9 (2), 159-168

Savaşır, I. (1994). Ölçekuyarlamasındakibazısorunlarveçözümyolları.TürkPsikolojiDergisi, 33 (9), 27-32.

Volk, K. S., \& Dugger, W. E. (2005). East Meets West: What Americans and Hong Kong people think about technology. Journal of Technology Education, 17(1), 53-68.

Williams, J. P. (2000). Design: The Only Methodology of Technology? Journal of Technology Education, 11(2), 48-60.

Yıldız, A., \& Baltacı, S. (2016). Reflections from the analytic geometry courses based on contextual teaching and learning through GeoGebra software. The Online Journal of New Horizons in Education (TOJNED), 6(4), 155-166.Zeidler, D. L., VValker, K. A., Ackett, W. A., \& Simmons, M. L. (2002). Tangled up in views: Beliefs in the nature of science and responses to socioscientific dilemmas, Science Education, 86(3), 343-367.

Zorlu, Y. (2011). Investigation of the preservice science and technology teachers' and preservice classroom teachers' views on nature of technology, Unpublished $\mathrm{PhD}$ thesis, Elazığ, Turkey. 